\title{
Biochemical and Histopathological Studies of Key Tissues in Healthy Male Wistar Rats Fed on African Yam Bean Seed and Tuber Meals
}

\author{
Omena Bernard Ojuederie, ${ }^{1,2}$ John Adebayo Ajiboye, ${ }^{3}$ and Olubukola Oluranti Babalola ${ }^{2}$ \\ ${ }^{1}$ Department of Biological Sciences, Biotechnology Unit, Bells University of Technology, Ota, Nigeria \\ ${ }^{2}$ Food Security and Safety Niche, Faculty of Natural and Agricultural Sciences, North-West University, Private Mail Bag X2046, \\ Mmabatho 2735, South Africa \\ ${ }^{3}$ Department of Chemical and Food Sciences, Bells University of Technology, Ota, Nigeria
}

Correspondence should be addressed to Olubukola Oluranti Babalola; olubukola.babalola@nwu.ac.za

Received 8 June 2020; Accepted 7 October 2020; Published 26 October 2020

Academic Editor: Antonio Piga

Copyright (C) 2020 Omena Bernard Ojuederie et al. This is an open access article distributed under the Creative Commons Attribution License, which permits unrestricted use, distribution, and reproduction in any medium, provided the original work is properly cited.

\begin{abstract}
Food insecurity and malnutrition are currently major issues affecting most developing countries, especially on the African continent. To mitigate this effect, focus is being given to orphan or underutilized crops with immense potentials to boost food and nutrition security in Africa, such as the African yam bean (AYB) Sphenostylis stenocarpa. The effect of AYB seed and tuber meals on the tissues of the kidney, liver, and testis of healthy male Wistar rats were investigated in this study. Four accessions of AYB were used for this study, TSs 107, TSs 140, AYB 45, and AYB 57. Thirty rats were randomly assigned into five groups $(n=6)$. Group I was fed on standard pelletized rat chow (control), Group II fed on 50\% seed meal, Group III fed on 100\% seed meal, Group IV fed on $50 \%$ tuber meal, and Group- $\mathrm{V}$ fed on $100 \%$ tuber meal. At the end of the treatments, the animals were sacrificed after $72 \mathrm{~h}$ under light ether anesthesia, and biochemical and histopathological analyses were conducted on the tissues. Phytate concentration

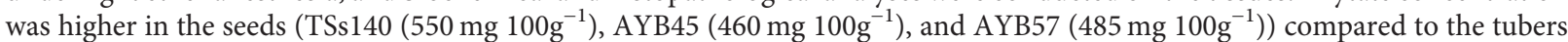

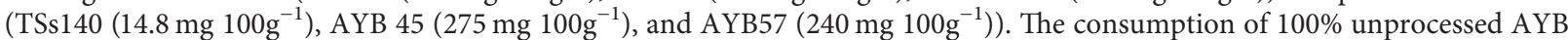
seeds caused liver and kidney damage in rats due to increased levels of aspartate aminotransferase $\left(5.04 \pm 1.62 \mathrm{U} \mathrm{L}^{-\mathrm{I}}\right)$, alanine aminotransferase $\left(8.46 \pm 2.43 \mathrm{U} \mathrm{L}^{-\mathrm{I}}\right)$, and lipid peroxidation $\left(0.27 \pm 0.02\right.$-unit $\mathrm{mg}^{-1}$ protein $)$. AYB tubers were innocuous to Wistar rats investigated. Good processing of AYB seeds is required for safe consumption by humans and livestock. This study has shown that tubers of AYB are safe for human consumption and should be utilized in meals as it contains fewer antinutrients and had no significant effect on the tissues examined in Wistar rats.
\end{abstract}

\section{Introduction}

The diet of most households in sub-Saharan Africa is deficient in protein and essential nutrients, especially among the rural poor. Some individuals cannot afford to purchase animal protein (fish, meat, and poultry products) to include in their diets; hence, they seek an alternative source in legumes. Legumes are used as the staple food at the subsistence level in nearly all parts of the world, and it is often eaten together with cereals and used as a substitute source of protein and calorific value for humans and livestock [1]. The major staple crops have received much focus over the years in enhancing food security with the disregard for underutilized crops with immense potentials as a substitute protein source and nutrition security crop [2]. One of such crops is Sphenostylis stenocarpa (Hochst ex. A. Rich), commonly called African yam bean [3]. It belongs to the Fabaceae family and stands out as the most valuable species out of all seven essential species of Sphenostylis [4-6]. The AYB produces two essential products, the underground root tuber and the edible yam bean seeds, which grow in pods above the ground [7]. The crop is cultivated mostly at the 
subsistence level, and only a little percentage of the grains produced is sold [8]. The genetic resources of AYB need to be preserved for use in genetic improvement/breeding programmes as it ranks well among neglected crops with great potentials as a food security crop [9]. The crop can produce root nodules and fix atmospheric nitrogen effectively in the soil [10].

The AYB seeds are rich in protein with high levels of essential amino acids, especially lysine and methionine, as well as carbohydrate, lipid, and minerals, making it a crop with remarkable nutritional potentials equivalent with other known grain legumes $[1,11,12]$. Nutritionally, the seed contains between $2-5 \%$ fat and $20-29 \%$ protein, $[2,4,9]$ as well as $2-4 \%$ fibre and $50-62 \%$ carbohydrate [1]. The tubers when cooked taste like potato, but unlike potato which has just $5 \%$ protein content, AYB tubers have $11-19 \%$ protein on a dry weight basis $[9,13]$. It could be used as a good alternative to cowpea, and it is highly consumed by the farmers who maintain the crops genetic resources $[3,9,14]$. AYB could be used as a substitute protein source for livestock and poultry given that a small amount AYB could replace soybean in the meal of weaner rabbits. The weights of white Leghorn layers, when fed with AYB meal, increased after proper processing [15]. Besides being used as a dietary protein, neglected grain legumes like AYB have comparatively higher free radical scavenging ability, as well as the ability to reduce cholesterol, and hence, they could be considered as a functional food [16].

Nonetheless, underutilized legumes contain antinutrients, such as trypsin inhibitors, and phytate which impedes protein digestibility and mineral availability due to their toxic nature which decreases the overall nutritional value in legumes [12]. AYB contains high concentrations of antinutrients such as trypsin inhibitor, phytate, tannin, oxalate, and alkaloids [17-19]. This attribute coupled with the hardness of the seed coat increases the time taken for cooking and processing the beans which are often consumed either alone or with yam, maize, and rice [20]. These antinutrients have discouraged the utilization and acceptability of AYB by consumers and subsistent farmers. Safety of humans and livestock can still be achieved through appropriate and efficient processing and cooking of the bean seeds of AYB before consumption to reduce the antinutritional factors present [11]. Notwithstanding the high nutritional worth and economic importance of AYB, it is still neglected with regards to research for crop improvement $[3,21]$. The pharmacological properties of AYB seeds possess pharmacological properties and reports have been made on the use of AYB for the treatment of different ailments such as gout, arthritis, and hypertension [20,22]. Aqueous extracts of the seed of AYB reduced the lipid profiles and sodium $\left(\mathrm{Na}^{+}\right)$concentration in the serum of experimental Wistar rats, with $3 \mathrm{ml}$ of aqueous extract of AYB reducing cholesterol and triglyceride levels more than the control [22].

In Nigeria and most West African countries, the seeds are consumed but the tubers, if harvested, are discarded due to the belief that tubers of AYB may be toxic to humans and livestock despite its rich nutritional content although the tubers are eaten in Central Africa. How the tubers are utilized in Africa is not fully known; however, its South American counterpart, the Mexican yam bean (Pachyrhizus erosus), is consumed in various ways; a well-known snack can be prepared if the tubers are sliced and pickled with onion and chili, a tasty milk can be produced from boiled milk containing grated tubers, chopped tubers are added to oriental stir-fries, or cooked tubers are eaten alone or together with other vegetables to prepare a soup [13]. Research on the effect of consumption of the tubers of AYB by Wistar rats will give us a better understanding of the possible effects it would have on humans and livestock. This study, therefore, investigated the effect of AYB seed and tuber meals on the liver, kidney, and testis of healthy male Wistar rats, to determine the level of toxicity, if any, when consumed.

\section{Materials and Methods}

2.1. Location of Study. This research was conducted in the Laboratory of the Department of Chemical and Food Sciences, College of Natural and Applied Sciences, Bells University of Technology, Ota, Ogun State, Nigeria.

2.2. Source of Plant Materials and Animals. The four accessions of AYB used in this study were obtained from the Genetic Resources Centre of the International Institute of Tropical Agriculture Ibadan (IITA), TSs 107 (mosaic seeds) and TSs 140 (mosaic seeds), and the Institute of Agricultural Research and Training moor plantation Ibadan (IAR\&T), AYB 45 (mosaic seeds) and AYB 57 (brown seeds). Thirty healthy adult male Wistar rats ( 45 days old) of about $200 \mathrm{~g}$ weight used in this study were obtained from the Department of Physiology, University of Ibadan, Nigeria [23].

2.3. Preparation of Samples. Tubers of the four AYB accessions (AYB57, AYB45, TSs107, and TSs140) were prepared using the method of Ogunlakin et al. [24]. The tubers were dried in an oven at $80^{\circ} \mathrm{C}$ for $24 \mathrm{~h}$ following the procedures given by Odebunmi et al. [25]. With the aid of an electric blender, the dried samples were milled into fine flour and sieved using a $250 \mathrm{~nm}$ stainless sieve and, subsequently, packaged in air-tight containers for analysis [1, 25]. AYB seeds of the same accessions were cleaned to remove extraneous matter, oven-dried, and milled to fine flour in the same way as the tubers for antinutritional analysis. The seed and tuber flours of the four accessions were made into separate composite meals for the Wistar rats (Supplementary Figure S1).

2.4. Determination of Antinutrients in African Yam Bean Seed and Tuber. The antinutritional factors, tannin, phytate, saponin, oxalate, and lectin, were determined following the official methods given by the Association of Analytical Chemists [26]. The spectrophotometric method was used for the determination of tannin, saponin, and phytate contents. The absorbance for the amount of tannins and saponins in the AYB samples was read at an optical density of $620 \mathrm{~nm}$, 
using a spectrophotometer, and the concentrations calculated as follows:

$$
\mathrm{PT}=\mathrm{Ab} \times \mathrm{S} \times \mathrm{Df} \times 100(\mathrm{mg} / \mathrm{g} \text { tannin }),
$$

where $\mathrm{PT}$ is the percentage tannin, $\mathrm{Ab}$ is the absorbance, $\mathrm{S}$ is the slope, and Df is the dilution factor [27].

$$
\text { Ps }-\mathrm{Ab} \times \mathrm{S} \times \mathrm{Dr} \times 100(\mathrm{mg} / \mathrm{kg} \text { saponin }) \text {, }
$$

where $\mathrm{Ps}$ is the percentage of saponin, $\mathrm{Ab}$ is the absorbance, $S$ is the slope, and Df is the dilution factor [27].

Saponin content of each sample was estimated from the standard saponin curve obtained from plotting the concentration of the standard against the absorbance [26-28]. The absorbance for the presence of phytate in the samples was measured at $420 \mathrm{~nm}$ using a spectrophotometer, and the concentration of phytate in each sample was calculated from a graph of known weights of phytate plotted against their absorbance [26-28]. Oxalate content was determined using the colorimetric method following the official procedures given by the Association of Analytical Chemists [26]. About $5 \mathrm{ml}$ of the extract of each sample was placed in a conical flask, and potassium permanganate in a burette was titrated against it. The appearance of a stable red colour was taken as the end point reading, and the concentration of oxalate $\left(\mathrm{mg} \mathrm{kg}^{-1}\right)$ calculated by multiplying the burette reading by a constant 11.5 [26-28]. Lectin content in AYB seeds and tubers were determined using the colorimetric method [26]. The absorbance of the AYB samples was measured at $510 \mathrm{~nm}$ using a spectrophotometer. The amount of lectin in each sample was estimated from the standard curve of lectin. Trypsin inhibitor and cyanogenic glycosides were determined following the procedures of Edeogu et al. [27].

2.5. Treatment of Animals. The rats were randomly placed into five groups $(n=6)$ and raised at the Department of Biochemistry's animal house at Bells University of Technology, Ota, Nigeria. They were acclimatized for 2 weeks and fed on a standard diet of pelletized rat chow with water given ad libitum at room temperature with a $12 \mathrm{~h}$ light and dark cycle before the experiment commenced [29]. The Animals Ethics Committee of the Institute of Medical Research and Training, University College Hospital, University of Ibadan, approved the experimental procedures used in this study. The five test groups and meal treatments were as follows:

Group-I Wistar rats fed on a standard pelletized rat chow (control group) + water ad libitum

Group II Wistar rats fed on 50\% African yam bean seed meal + water ad libitum

Group III Wistar rats fed on $100 \%$ African yam bean seed meal + water ad libitum

Group IV Wistar rats fed on 50\% African yam bean tuber meal + water ad libitum

Group-V Wistar rats fed on $100 \%$ African yam bean tuber meal + water ad libitum
Humane care was given to the experimental rats following the advice given in the Guidelines for the Care and Use of Laboratory Animals [23,30]. Seventy-two hours after administration of the treatments, the rats were sacrificed using light ether anesthesia.

2.6. Antioxidant Assays. The organs harvested from the rats were homogenized in $50 \mathrm{Mm}$ Tris HCL buffer ( $\mathrm{pH} 7.4$ ) which contained $1.15 \% \mathrm{KCL}$, and the homogenate was centrifuged at $10,000 \mathrm{~g}$ for $15 \mathrm{~min}$ at $4^{\circ} \mathrm{C}$ [23]. The supernatant was collected, and catalase (CAT) activity was estimated using hydrogen peroxide as a substrate [23].

2.6.1. Superoxide Dismutase (SOD). The SOD activity was determined by calculating the inhibition of autoxidation of epinephrine at $\mathrm{pH} 10.2$ at $30^{\circ} \mathrm{C}$ [31]. The amount of total protein produced was determined by Lowry's method [32], and reduced glutathione (GSH) was determined at $412 \mathrm{~nm}$ [33].

2.6.2. Lipid Peroxidation Assay. Spectrophotometry was used to determine lipid peroxidation at $532 \mathrm{~nm}$ by thiobarbituric acid reactive substances and malondialdehyde (MDA) estimated in $\mathrm{mmol} \mathrm{g}^{-1}$ tissue [32].

2.6.3. Assay of Serum Alanine Aminotransferase and Aspartate Aminotransferase Activity. The method of Gowda et al. [34] was used to determine the serum concentrations of alanine aminotransferase (ALT) and aspartate aminotransferase (AST). ALT was recorded by checking the concentration of pyruvate hydrazones produced with 2, 4 dinitrohydrazine.

2.7. Histopathological Analysis. The three organs from the Wistar rats (kidney, liver, and testis) were sliced in bits and prepared by fixing in Bouin's fixative for $6 \mathrm{~h}$ [23], followed by treatment with formalin. The tissues were, then, sectioned and stained with hematoxylin and eosin for histopathological examination [23]. A light microscope was used to produce stable photomicrographs.

2.8. Statistical Analysis. Data collected were checked for normality and, then, analyzed with a one-way analysis of variance. Significantly different means were separated using Least Significant Difference $(p<0.05)$. The antinutritional composition of AYB seeds and tubers were compared using the paired $t$-test. All the results are expressed as mean$\mathrm{s} \pm$ standard deviation (SD) with six rats per group. Statistical Analysis Software version 9.3 was used for the analyses $9.3[23,35]$.

\section{Results and Discussion}

This study investigated the effects of AYB seed and tuber flour meals on the liver, kidney, and testis of healthy male Wistar rats. The enzymatic activity of alanine 
aminotransferase and aspartate aminotransferase was studied to assess liver malfunctions. The analysis of variance revealed that AST and ALT concentrations were significantly $(p<0.05)$ higher in both the kidney and liver of rats fed with $100 \%$ seed flour meal compared to the other meal types. The concentrations of AST and ALT were significantly lower in the organs of rats fed with $50 \%$ and $100 \%$ tuber flour compared to rats fed with $50 \%$ and $100 \%$ seed flour (Table 1).

This study confirmed that the consumption of unprocessed 100\% AYB seeds caused liver and kidney damage in rats as revealed by elevated serum concentrations of the two enzymes used as biomarkers, aspartate aminotransferase (AST), and alanine aminotransferase (ALT) compared to other meal types. The cellular integrity of the liver is affected by the plasma levels of ALT, AST, and total protein which also determines its functionality [36]. Estimation of AST and ALT levels in the serum is often used as a quantifiable biomarker for detection of hepatocellular damage and liver malfunction [23]. Rats fed on 50\% and $100 \%$ tuber flour meals had reduced levels of AST and ALT in the serum, which meant that there was no damage to the liver. In contrast, higher values obtained for AST and ALT could be as a result of severe damage to kidney and liver in rats fed with $50 \%$ and $100 \%$ seed flour meal. Antioxidants are fundamental to maintaining homeostasis within living organisms. The main enzymes involved include superoxide dismutase, catalase, and glutathione reductase which were investigated in this study.

Hundred percent seed meal generated oxidative stress in the kidney of rats. There were moderate renal cortical congestion and mild necrosis (100\% tuber meal) and mild renal cortical congestion (50\% tuber meal) in the kidneys of the rats investigated (Figures 1(a) and 1(b)). No visible lesion was observed in the control (Figure 1(c)). Severe diffuse degeneration and necrosis of renal tubules in the kidney of rats were observed in rats fed on $100 \%$ seed meal (Figure 1(d)). Protein casts were also observed in the tubular lumen of fed rats. Moderate renal cortical congestion and mild necrosis were observed in the kidney of rats fed with $50 \%$ seed meal (Figure 1(e)). No visible lesions were observed in the control fed with rat chow (Figure 1(f)). Histopathologically, kidney sections from rats fed with rat chow revealed normal renal architecture, whereas severe diffuse degeneration and necrosis of renal tubules and protein casts in the tubular lumen were observed in the kidney of $100 \%$ seed meal fed rats possibly due to generation of oxidative stress in the kidney of the fed Wistar rats.

The effect of AYB seed and tuber meals on levels of superoxide dismutase, lipid peroxidation (LPO), reduced glutathione, catalase, and total protein in the kidney of healthy Wistar rats $72 \mathrm{~h}$ after administration of the treatments is presented (Figure 2). The levels of SOD, CAT, and total protein had no significant effect on the kidney as in the control group (Figures 2(a) and 2(b)). However, the results revealed that there were significant reductions in LPO (MDA) levels in the kidney of rats fed on 50\% tuber and 50\% seed meals compared to $100 \%$ seed meal which had the highest value (Figure 2(a)). GSH levels were not significantly different $(p>0.05)$ in groups II to V, but the control group
TABLE 1: Effect of AYB seed and tuber meal on Plasma AST and ALT levels in Wistar rats.

\begin{tabular}{lcc}
\hline Treatments & AST concentration & ALT concentration \\
\hline $100 \%$ seed flour & $5.04 \pm 1.62^{\mathrm{a}}$ & $8.46 \pm 2.43^{\mathrm{a}}$ \\
$50 \%$ seed flour & $3.42 \pm 0.63^{\mathrm{b}}$ & $4.43 \pm 0.10^{\mathrm{b}}$ \\
$100 \%$ tuber flour & $0.41 \pm 0.36^{\mathrm{c}}$ & $2.96 \pm 0.7^{9 \mathrm{bc}}$ \\
$50 \%$ tuber flour & $0.72 \pm 0.28^{\mathrm{c}}$ & $2.20 \pm 0.45^{\mathrm{c}}$ \\
Rat chow & $1.18 \pm 0.68^{\mathrm{c}}$ & $2.54 \pm 0.62^{\mathrm{c}}$ \\
\hline
\end{tabular}

Means followed by the same letters are not significantly different $(p<0.05)$ using Least Significant Difference. AST $\left(\mathrm{U} \mathrm{L}^{-1}\right)$ and ALT $\left(\mathrm{U} \mathrm{L}^{-\mathrm{I}}\right)$ values are presented as means $\pm \mathrm{SD}$.

(Group I) fed with rat chow had significantly lower GSH levels (Figure 2(b)).

The levels of SOD, GSH, and total protein in the liver of rats $72 \mathrm{~h}$ after administration of the treatments were not significantly different from the control group fed with rat chow (Figures 3(a) and 3(b)). Lipid peroxidation (LPO) was significantly $(p<0.01)$ increased in rats fed on $100 \%$ seed meal compared to the other meal types, as well as the control group (Figure 3(a)). Moreover, there was also a significant increase in liver catalase activity in rats fed on $100 \%$ seed meal which was not significantly different from rats in Group-V and Group-II fed on 100\% tuber and 50\% seed meals, respectively (Figure 3(b)). The control group fed with rat chow had the least catalase concentration $(891.6 \pm 54.4)$ followed by Group-IV rats fed on 50\% tuber meal. The 50\% and $100 \%$ tuber flour meals did not affect the liver of the treated rats. GSH levels were not significant in all treatments (Figure 3(b)).

The $50 \%$ and $100 \%$ tuber flour meals had no effect on the liver. Severe portal and central venous congestion were observed in the liver of rats fed with $100 \%$ seed meal. Rats fed with $50 \%$ seed meal had mild periportal hepatic necrosis and severe periportal infiltration by mononuclear cells (Figure 4). The effect of AYB seed and tuber meals on SOD, LPO, $\mathrm{GSH}, \mathrm{CAT}$, and total protein on the testis of healthy Wistar albino rats $72 \mathrm{~h}$ after administration is presented in Table 2. The results indicated that SOD levels in the testis were significantly $(p<0.01)$ reduced in rats fed on $50 \%$ tuber meal compared to the other treatments. Nonetheless, there were no significant differences in SOD levels in rats fed on rat chow (control), $50 \%$ seed, $100 \%$ seed, and $100 \%$ tuber meals. Likewise, there was no significant variation in the levels of GSH and LPO in the testis. Catalase concentration was, however, elevated in rats fed on $100 \%$ seed and $100 \%$ tuber meals by $31.43 \%$ and $29.09 \%$, respectively, than in the control treatment. Nevertheless, there was a considerable reduction in catalase concentration in rats fed on rat chow and $50 \%$ tuber meals (Table 2). The total protein level was also significantly reduced by $20.83 \%$ in rats fed on $50 \%$ and $100 \%$ tuber meals than the control and by $12.50 \%$ than in rats fed on $100 \%$ seed meal where it was significantly $(p<0.001)$ increased (Table 2). No lesions were seen in the testis for all the treatments (Supplementary Figure S2).

Hundred percent seed meal generated an unevenness between the free radicals produced $[36,37]$ and the ability of the liver and kidney to detoxify the negative effects through 


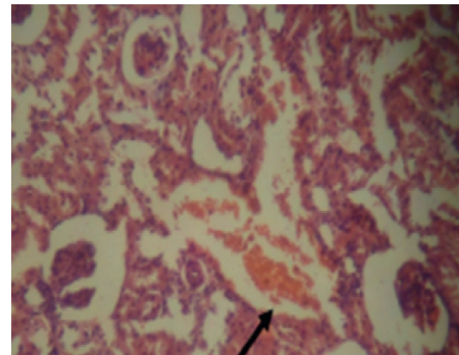

Moderate renal cortical congestion and mild necrosis (100\% tuber meal)

(a)

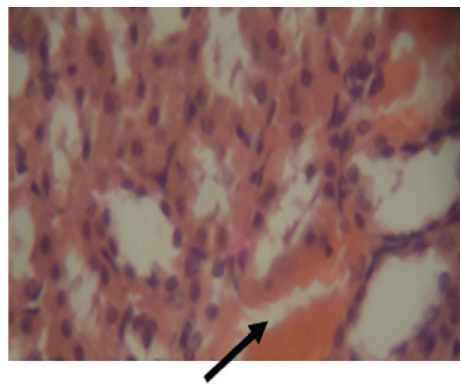

Severe diffuse degeneration and necrosis of the renal tubules and protein casts in the tubular lumen (100\% seed meal)

(d)

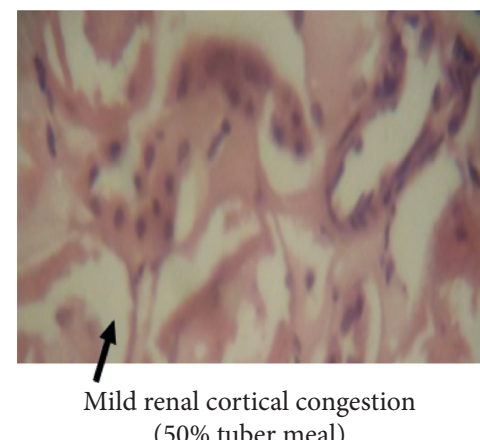

(50\% tuber meal)

(b)

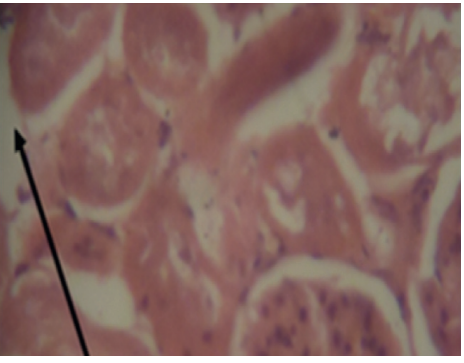

Moderate renal cortical congestion and mild necrosis ( $50 \%$ seed meal)

(e)

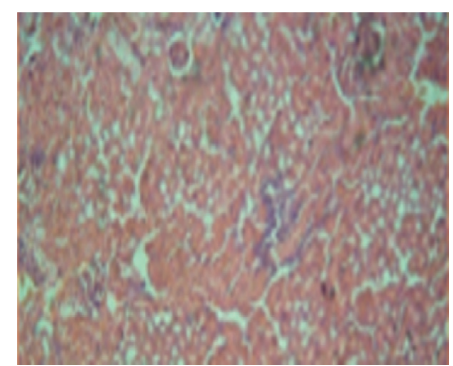

Control-No visible lesions seen

(c)

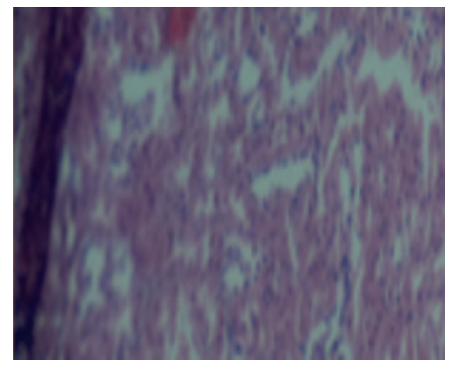

Control-No visible lesions seen

(f)

FIGURE 1: Effect of (a) 100\% tuber meal, (b) 50\% tuber meal, (d) 100\% seed meal, and (e) 50\% seed meal, on the kidney of Wistar albino rats. (c and $\mathrm{f}$ ) Rat chow (control) original magnification $\times 240$.

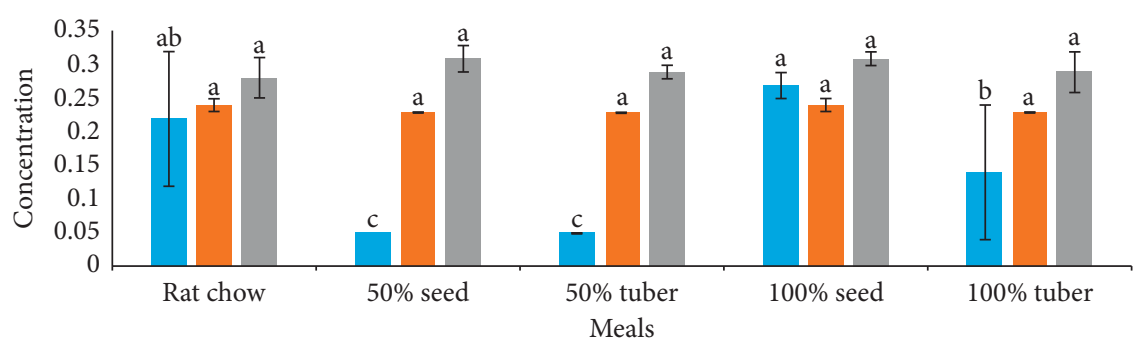

- Lipid peroxifdation

- Total protein

- Super oxide dismutase

(a)

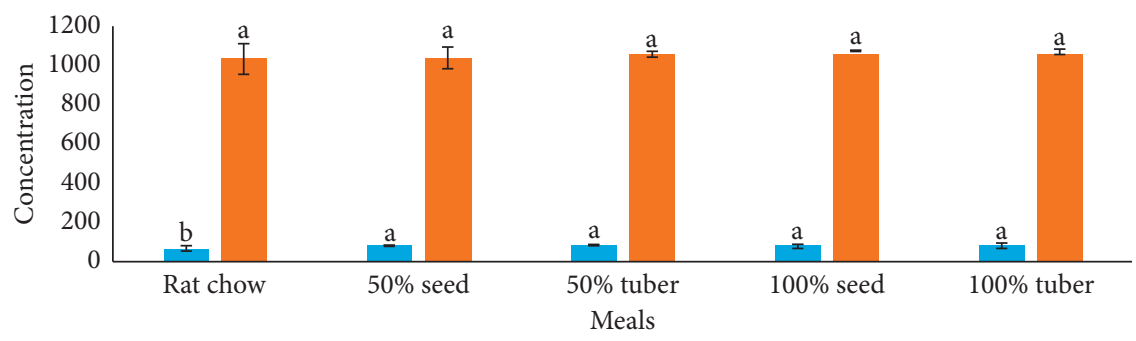

- Reduced glutathione

- Catalase

(b)

Figure 2: Effect of AYB seed and tuber meals on the levels of (a) lipid peroxidation (LPO), total protein, and superoxide dismutase; (b) reduced glutathione (GSH) and catalase in the kidney of healthy Wistar rats $72 \mathrm{~h}$ after administration. All values are expressed as Mean \pm SD $(n=6)$. Means followed by the same letters are not significantly different $(p<0.05)$. SOD (unit $\mathrm{mg}^{-1}$ protein), GSH (mmoles $\mathrm{min}^{-1} \mathrm{mg}^{-1}$ protein), LPO (unit $\mathrm{mg}^{-1}$ protein), catalase (mmoles $\mathrm{min}^{-1} \mathrm{mg}^{-1}$ protein), total protein ( $\mathrm{mg}^{-1}$ protein). 


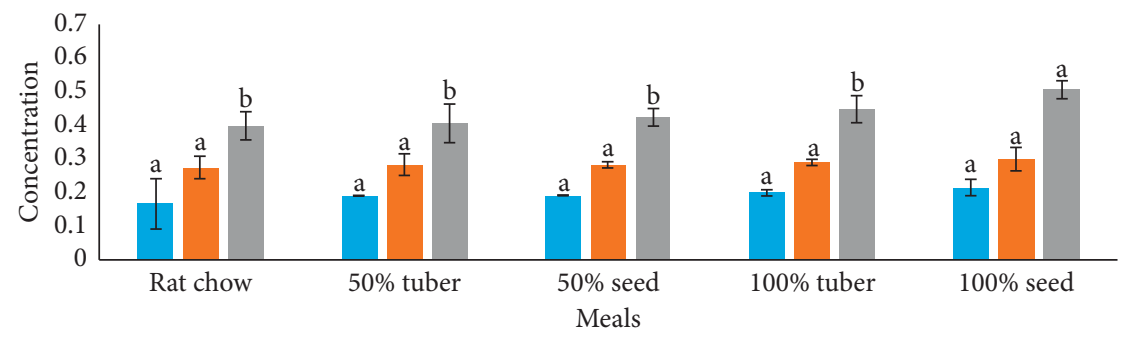

- Total protein

- Superoxide dismutase

- Lipid peroxidation

(a)

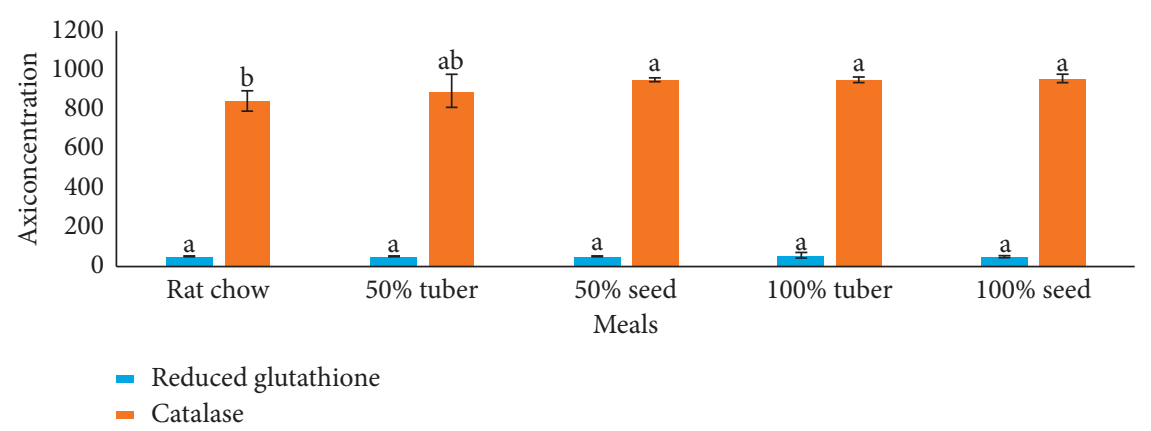

(b)

Figure 3: Effect of AYB seed and tuber meals on the levels of (a) lipid peroxidation (LPO), total protein, and superoxide dismutase; (b) reduced glutathione (GSH) and catalase in the liver of healthy Wistar rats $72 \mathrm{~h}$ after administration. Means followed by the same letters are not significantly different $(p<0.05)$. SOD (unit $\mathrm{mg}^{-1}$ protein), GSH (mmoles $\mathrm{min}^{-1} \mathrm{mg}^{-1}$ protein), LPO (unit mg ${ }^{-1}$ protein), catalase (mmoles $\mathrm{min}^{-1} \mathrm{mg}^{-1}$ protein), and total protein $\left(\mathrm{mg}^{-1}\right.$ protein).

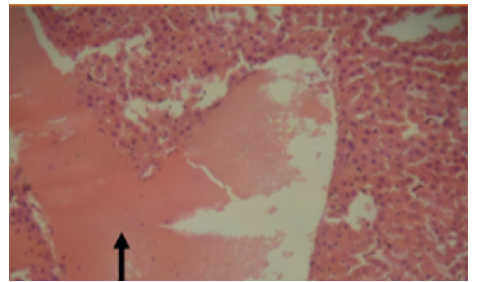

Severe portal and central venous congestion (100\% seed meal)

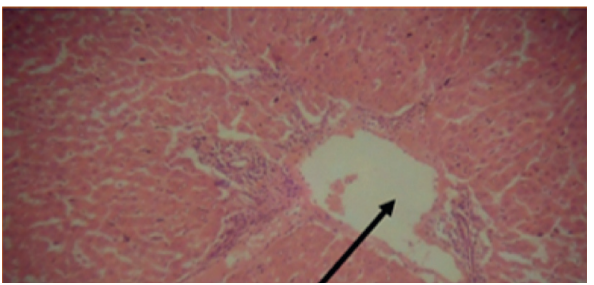

Mild periportal hepatic necrosis, and severe periportal infiltrations by mononuclear cells (50\% seed meal)

(a)

(b)

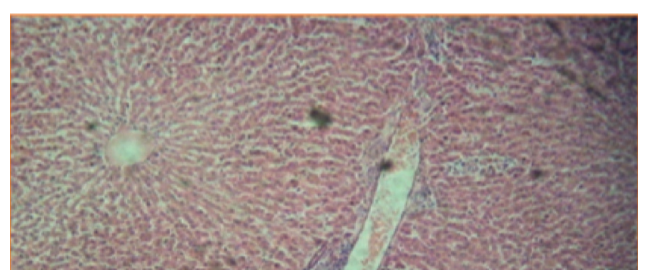

No visible lesions seen

(c)

Figure 4: Effect of (a) 100\% seed meal and (b) 50\% seed meal on the liver of Wister albino rats. (c) Rat chow (control).

neutralization by the antioxidant defense mechanisms. Oxidative stress is a pathological condition caused by the disparity between the development and removal of reactive oxygen species (ROS) derived from free radicals and the potential of a biological system to get rid of the reactive intermediates and return the system to its regular state $[38,39]$. Oxidative stress causes base damage by the formation of ROS such as $\mathrm{O}_{2}^{-}$(superoxide radical), $\mathrm{OH}^{-1}$ 
TABLE 2: Effect of African yam bean seed and tuber meal on superoxide dismutase (SOD), lipid peroxidation (LPO), reduced glutathione (GSH), catalase, and total protein on the testis of healthy Wistar albino rats $72 \mathrm{~h}$ after administration.

\begin{tabular}{lccccc}
\hline Meals & SOD & GSH & LPO & Catalase & Total protein \\
\hline Rat chow & $0.31 \pm 0.05^{\mathrm{a}}$ & $60.43 \pm 4.34^{\mathrm{a}}$ & $0.22 \pm 0.10^{\mathrm{a}}$ & $859.77 \pm 61.33^{\mathrm{c}}$ & $0.29 \pm 0.02^{\mathrm{a}}$ \\
$50 \%$ tuber & $0.27 \pm 0.01^{\mathrm{b}}$ & $59.62 \pm 1.60^{\mathrm{a}}$ & $0.21 \pm 0.03^{\mathrm{a}}$ & $917.05 \pm 83.80^{\mathrm{c}}$ & $0.24 \pm 0.01^{\mathrm{c}}$ \\
$50 \%$ seed & $0.34 \pm 0.02^{\mathrm{a}}$ & $61.32 \pm 2.45^{\mathrm{a}}$ & $0.23 \pm 0.04^{\mathrm{a}}$ & $994.38 \pm 1.25^{\mathrm{b}}$ & $0.26 \pm 0.00^{\mathrm{b}}$ \\
$100 \%$ tuber & $0.34 \pm 0.02^{\mathrm{a}}$ & $59.32 \pm 5.34^{\mathrm{a}}$ & $0.25 \pm 0.03^{\mathrm{a}}$ & $1109.86 \pm 64.21^{\mathrm{a}}$ & $0.24 \pm 0.01^{\mathrm{c}}$ \\
$100 \%$ seed & $0.34 \pm 0.02^{\mathrm{a}}$ & $61.92 \pm 4.38^{\mathrm{a}}$ & $0.26 \pm 0.02^{\mathrm{a}}$ & $1130.03 \pm 88.48^{\mathrm{a}}$ & $0.27 \pm 0.02^{\mathrm{a}}$ \\
Mean & 0.32 & 60.52 & 0.23 & 1002.22 & 0.26 \\
LSD $(\alpha=0.05)$ & 0.03 & 5.43 & 0.07 & 68.16 & 0.01 \\
\hline
\end{tabular}

Means followed by the same letters are not significantly different $(p<0.05)$ using Least Significant Difference. SOD (unit mg ${ }^{-1} \mathrm{protein}$ ), GSH (mmoles $\mathrm{min}^{-1} \mathrm{mg}^{-1}$ protein), LPO (unit $\mathrm{mg}^{-1}$ protein), catalase (mmoles $\mathrm{min}^{-1} \mathrm{mg}^{-1}$ protein), and total protein (mg protein) values are presented as means \pm SD $(n=6)$.

(hydroxyl radical), and $\mathrm{H}_{2} \mathrm{O}_{2}$ hydrogen peroxide in addition to fragmentation of the genetic material, the DNA [38]. Superoxide dismutase, catalase, and glutathione peroxidase, as well as nonenzymatic compounds such as tocopherol ascorbic acid and glutathione, give protection to cells against oxidative stress by reducing free radical concentrations $[39,40]$. Under conditions of oxidative stress, activities of these enzymes are elevated. Soetan et al. [34] also made such observations on the liver and kidney of rats fed with Lablab purpureus seeds. When the capacity of antioxidant systems is reduced, ROS concentrations increase which perpetually distorts the permeability of the mitochondria and induces the release of enzymes that activate cell death [41].

The different treatments of Sphenostylis stenocarpa seed and tuber flour meals fed to Wistar rats did not have any significant difference in renal SOD and hepatic SOD activity, but $100 \%$ seed meal increased CAT and GSH activities in both liver and renal tissues compared to the control group. Comparable results were also obtained by Soetan et al. [34]. Lipid peroxidation and liver catalase activity were also observed to be elevated in rats fed on $100 \%$ seed meal compared to $50 \%$ and $100 \%$ tuber meals. Studies have shown that CAT protects cells under oxidative stress, and it is also the most adaptive antioxidant enzyme [34, 42]. The elevated level of CAT activity, therefore, could be attributable to an adaptive response to high concentrations of $\mathrm{H}_{2} \mathrm{O}_{2}$ during the treatment with $100 \%$ seed meal of AYB. Akintunde et al. [23] stated that $\mathrm{H}_{2} \mathrm{O}$ and $\mathrm{O}_{2}$ are produced by free radicals or by superoxide dismutase during elimination of superoxide anions from the breakdown of hydrogen peroxide by catalase. Rats fed on $100 \%$ seed and $100 \%$ tuber meals exhibited higher levels of catalase than the control. This could be as a result of production of too much $\mathrm{H}_{2} \mathrm{O}_{2}$ arising from other intermediary metabolism in the kidney and liver when rats were fed on $100 \%$ seed and tuber meals. Lipid peroxidation is induced by free radicals which results in reactive molecules such as malondialdehyde (MDA), used as a biomarker for lipid peroxidation. Lipid peroxidation (LPO) disrupts the integrity of plasma membranes and causes damage to the tissues. Malondialdehyde levels were significantly increased in the liver and kidney of rats fed with $100 \%$ seed meal which may be attributed to the increased generation of the ROS and an altered antioxidant defense system. No damage was observed in the testis of rats investigated. Thus, the histological changes observed cannot be transferred via sexual reproduction, not been genetic. The increase in total protein level by $50 \%$ and $100 \%$ seed meals is indicative of a rise in the globulin portion of the total protein functioning to combat infections in the rats which could be an indication of damage to some organs.

The analysis of the tubers and seeds of the four AYB accessions TSs107, TSs140, AYB45, and AYB57 revealed that antinutritional factors: phytate, oxalate, and tannin were more in seeds (Supplementary Figure S3(a)) compared to tubers (Supplementary Figure S3(b)). Nevertheless, saponin

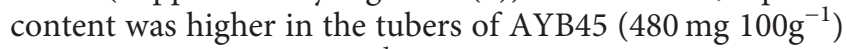
and AYB57 (540 mg 100g ${ }^{-1}$ ) compared to the seeds (350 mg $\left.100 \mathrm{~g}^{-1}\right)$. Higher levels of oxalate were obtained in the seeds

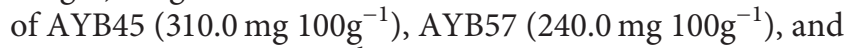
TSs140 (250.0 mg $100 \mathrm{~g}^{-1}$ ) but lower in both seeds $(80 \mathrm{mg}$ $\left.100 \mathrm{~g}^{-1}\right)$ and tubers $\left(30 \mathrm{mg} 100 \mathrm{~g}^{-1}\right)$ of TSs107. Phytate also followed the same trend as that of oxalate concentration with TSs107 having the same concentration in both seeds and tubers. On the other hand, tannins had a higher concentration in the tubers of AYB45 and AYB57 but a lower concentration in the tubers of TSs107 and TSs140. Lectin concentration was almost the same in both seeds and tubers of AYB45, slightly higher in the seeds of AYB57 but only present in higher concentrations in the seeds of TSs107 (58.4 $\mathrm{Lu} \mathrm{mg}{ }^{-1}$ ) and TSs $140\left(61.2 \mathrm{Lu} \mathrm{mg}^{-1}\right)$ and absent in the tubers. The paired $t$-test comparison revealed considerable differences in the concentrations of antinutrients in the seeds and tubers of AYB with the seeds generally having higher concentrations for most antinutrients than tubers (Table 3).

The concentration of ANFs oxalate, phytate, tannin, and saponin was higher in the seeds of AYB used for meal formulation compared to the tubers. This could be responsible for the noxious effect of the seed flour meal on the rats. Oxalate, if consumed in large quantities, blocks the renal tubules by forming calcium oxalate crystals and development of urinary calculi [43], which can lead to renal failure and, hence, death in vulnerable individuals. Oxalic acid affects the bioavailability of minerals, especially calcium, as it forms insoluble calcium oxalate with calcium which is not absorbed in the body [44]. Phytate binds to minerals making them unavailable to animals while tannin causes a decrease in feed consumption, palatability, and reduced growth [45]. Phytate chelates ions, thereby reducing 
TABle 3: Paired $t$-test comparison of the antinutritional composition of African yam bean seeds and tubers used in meal formulation for Wister rats.

\begin{tabular}{|c|c|c|c|}
\hline Accessions & Antinutrients & Seed & Tuber \\
\hline TSs107 & Oxalate $\left(\mathrm{mg} 100 \mathrm{~g}^{-1}\right)$ & 80.0 & 30.0 \\
\hline TSs 140 & Oxalate $\left(\mathrm{mg} 100 \mathrm{~g}^{-1}\right)$ & 250.0 & 60.0 \\
\hline AYB45 & Oxalate $\left(\mathrm{mg} 100 \mathrm{~g}^{-1}\right)$ & 310.0 & 80.0 \\
\hline AYB57 & Oxalate $\left(\mathrm{mg}^{100 \mathrm{~g}^{-1}}\right)$ & 240.0 & 115.0 \\
\hline TSs 107 & Phytate (mg $\left.100 \mathrm{~g}^{-1}\right)$ & 205.0 & 17.5 \\
\hline TSs 140 & Phytate (mg $100 \mathrm{~g}^{-1}$ ) & 550.0 & 14.8 \\
\hline AYB45 & Phytate (mg $\left.100 \mathrm{~g}^{-1}\right)$ & 460.0 & 275.0 \\
\hline AYB57 & Phytate (mg $100 \mathrm{~g}^{-1}$ ) & 485.0 & 240.0 \\
\hline TSs 107 & Tannin $\left(\mathrm{mg} 100 \mathrm{~g}^{-1}\right)$ & 660.0 & 11.0 \\
\hline TSs 140 & Tannin $\left(\mathrm{mg}^{100 \mathrm{~g}^{-1}}\right)$ & 200.0 & 8.0 \\
\hline AYB45 & Tannin (mg $\left.100 \mathrm{~g}^{-1}\right)$ & 189.5 & 480.0 \\
\hline AYB57 & Tannin $\left(\mathrm{mg} 100 \mathrm{~g}^{-1}\right)$ & 215.0 & 540.0 \\
\hline TSs 107 & Saponin $\left(\mathrm{mg}^{\left.100 \mathrm{~g}^{-1}\right)}\right.$ & 440.0 & 3.0 \\
\hline TSs 140 & Saponin $\left(\mathrm{mg}^{\left.100 \mathrm{~g}^{-1}\right)}\right.$ & 330.0 & 5.0 \\
\hline AYB45 & Saponin $\left(\mathrm{mg}^{\left.100 \mathrm{~g}^{-1}\right)}\right.$ & 351.0 & 275.0 \\
\hline AYB57 & Saponin $\left(\mathrm{mg}^{100 \mathrm{~g}^{-1}}\right)$ & 350.0 & 225.0 \\
\hline TSs 107 & Trypsin inhibitor (TIU $\mathrm{mg}^{-1}$ ) & 34.6 & 0.0 \\
\hline TSs 140 & Trypsin inhibitor (TIU $\mathrm{mg}^{-1}$ ) & 34.9 & 0.0 \\
\hline AYB45 & Trypsin inhibitor (TIU $\mathrm{mg}^{-1}$ ) & 34.5 & 34.1 \\
\hline AYB57 & Trypsin inhibitor (TIU $\mathrm{mg}^{-1}$ ) & 37.1 & 33.8 \\
\hline TSs 107 & Lectin $\left(\mathrm{Lu} \mathrm{mg}^{-1}\right)$ & 58.4 & 0.0 \\
\hline TSs 140 & Lectin $\left(\mathrm{Lu} \mathrm{mg}^{-1}\right)$ & 61.2 & 0.0 \\
\hline AYB45 & Lectin $\left(\mathrm{Lu} \mathrm{mg}^{-1}\right)$ & 57.6 & 57.2 \\
\hline AYB57 & Lectin $\left(\mathrm{Lu} \mathrm{mg}^{-1}\right)$ & 59.1 & 56.7 \\
\hline TSs 107 & Cyanogenic glycoside $\left(\mathrm{mg} 100 \mathrm{~g}^{-1}\right)$ & 6.1 & 0.9 \\
\hline TSs 140 & Cyanogenic glycoside $\left(\mathrm{mg} 100 \mathrm{~g}^{-1}\right)$ & 6.9 & 0.9 \\
\hline AYB45 & Cyanogenic glycoside $\left(\mathrm{mg} 100 \mathrm{~g}^{-1}\right)$ & 6.9 & 6.4 \\
\hline AYB57 & Cyanogenic glycoside $\left(\mathrm{mg} 100 \mathrm{~g}^{-1}\right)$ & 6.8 & 6.3 \\
\hline Mean & & 204.3 & 91.9 \\
\hline CV (\%) & & 92.8 & 159.1 \\
\hline
\end{tabular}

$t(0.05)$ for comparing the two means $=2.88$.

the availability of calcium, and inhibits the absorption of iron as a result of calcium phytate complexes produced [45]. Higher concentration of phytate was observed in the seeds of

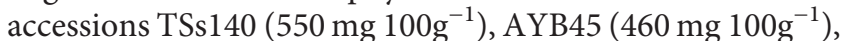
and AYB57 (485 $\mathrm{mg} \mathrm{100g}^{-1}$ ) used for formulation of the seed

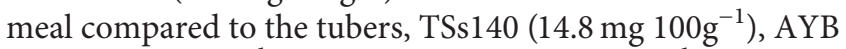

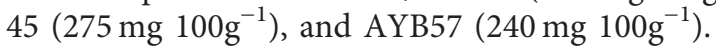

Exploiting the natural variation in phytate accumulation in AYB genotypes could lead to selection of genotypes with low phytate content that could improve micronutrient bioavailability [46, 47]. Tannin was the highest in the seeds of accession TSs107 $\left(600 \mathrm{mg} \mathrm{100g}^{-1}\right)$ compared to the tuber $\left(11 \mathrm{mg} 100 \mathrm{~g}^{-1}\right)$. The high concentration of tannins had undesirable effects on the digestive tract of rats due to the noxious nature of the metabolites. This could explain why the albino rats ate less of the seed meal but consumed all the tuber meal. Seeds that contain saponin cause reduction in methane production in the rumen of livestock by suppressing protozoa which influences butyrate production during rumen methanogenesis.

An increase in the concentration of saponin in legumes seeds leads to a reduction in the amount of methane made in the rumen. This leads to energy loss derivable from a feedstuff by the animal. Saponins cause cytotoxic permeabilization of the intestines through its biological activities depending on the structure [43]. Elevated levels of saponin was obtained in the seeds of unprocessed AYB accessions TSs107 (440 mg 100g $\left.{ }^{-1}\right)$, TSs140 (330 mg 100 $\left.\mathrm{g}^{-1}\right)$, AYB 45 (351 mg $100 \mathrm{~g}^{-1}$ ), and AYB57 (350 mg $\left.100 \mathrm{~g}^{-1}\right)$ ) compared to the tubers (TSs107 $\left(3 \mathrm{mg}^{100 \mathrm{~g}^{-1}}\right)$, TSs $140(5 \mathrm{mg}$ $\left.100 \mathrm{~g}^{-1}\right)$, AYB45 $\left(275 \mathrm{mg} 100 \mathrm{~g}^{-1}\right)$, and AYB57 (225 mg $\left.100 \mathrm{~g}^{-1}\right)$ ), respectively.

Recent studies by Ojuederie and Balogun [1] on the proximate and mineral composition of the four AYB accessions used in this study revealed that, on average, the tubers contained crude protein (15.5\%), moisture content (10.4\%), total ash (2.9\%), crude fibre (2.4\%), crude fat $(1.3 \%)$, carbohydrate (68.3\%), and a calorific value of $1445.70 \mathrm{Kj} \mathrm{g}^{-1}$ and had high amounts of potassium $\left(10.10 \mathrm{~g} \mathrm{~kg}^{-1}\right)$, magnesium $\left(1.67 \mathrm{~g} \mathrm{k}^{-1}\right)$, and iron $\left(0.08 \mathrm{~g} \mathrm{~kg}^{-1}\right)$, respectively $[1,14]$. Unprocessed seeds of AYB studied had higher antinutritional contents which can be eliminated or reduced by appropriate processing methods to assure safety of AYB meals consumed by humans and livestock [11]. Roasting eliminates or reduces the amount of phytate in seeds more efficiently than boiling, while boiling eliminates oxalate from seeds much better than roasting [48]. These processing methods improve the bioavailability of minerals while reducing the antinutritional contents of the seeds as confirmed by Ndidi et al. [12]. Thus, based on the low antinutritional contents of the tubers of AYB and high nutritional composition, especially the significant amount of protein (15.5\%), consumption of well-processed AYB seeds and the edible tubers will boost food and nutrition security, and reduce protein malnutrition in sub-Saharan Africa if utilized in meals.

\section{Conclusions}

Consumption of $100 \%$ AYB seed meal induced hepatorenal toxicity in Wistar rats by the induction of oxidative stress which makes the environment susceptible to diseases, and lipid peroxidation was induced by free radicals which increased the levels of malondialdehyde. The tubers of AYB are safe for human consumption and could be used in animal feeds as they did not trigger any toxic effect on the tissues and organs of Wistar rats investigated. To utilize the seeds of AYB in animal feeds, appropriate processing methods need to be carried out to reduce the levels of antinutritional factors which were found to be more concentrated in the seeds and enhance the bioavailability of minerals and nutrients. Trypsin inhibitors and lectin were not identified in tubers of TSs 107 and TSs 140 while cyanogenic glycoside was negligible. This makes these accessions useful candidates in breeding programs for development of new varieties with low antinutritional factors. This study will help researchers to unearth the knowledge gap in the antinutrient composition of AYB tubers that many researchers have not explored. Thus, the benefits of eating the tubers of AYB may be achieved.

\section{Data Availability}

All data used to support the findings of this study are included in the article. 


\section{Conflicts of Interest}

The authors have declared that no conflicts of interest exist.

\section{Acknowledgments}

The authors express their gratitude to Dr. O.O. Aina of the Veterinary Anatomy Department of the University of Ibadan, Nigeria, for the histopathological studies and analysis. The authors are also grateful to the International Institute of Tropical Agriculture and the Institute of Agricultural Research and Training Ibadan, Nigeria, for providing the seeds of the accessions used in this study. This work was supported by a research grant (No. C/5250-1) from the International Foundation for Science (IFS) awarded to the first author.

\section{Supplementary Materials}

Figure S1: African yam bean seed and tuber flour meal formulation for Wistar rats. Figure S2: effect of treatments on the testis of Wister albino rats: (d) 100\% tuber meal, (e) $100 \%$ seed meal, (f) 50\% tuber meal, (g) 50\% seed meal, and (h) rat chow (control). No visible lesions were observed. Original magnification $\times 240$. Figure S3: (a) antinutritional factors in African yam bean seeds; (b) antinutritional factors in African yam bean tubers. (Supplementary Materials)

\section{References}

[1] O. B. Ojuederie and M. O. Balogun, "Genetic variation in nutritional properties of african yam bean (Sphenostylis stenocarpa hochst ex. A. Rich. Harms) accessions," Nigerian Journal of Agriculture, Food and Environment, vol. 13, pp. 180-187, 2017.

[2] C. O. Aremu, O. B. Ojuederie, F. Ayo-Vaughan et al., "Morphometric analysis and characterization of the nutritional quality in African yam bean accessions," Plant Physiology Reports, vol. 24, no. 3, pp. 446-459, 2019.

[3] K. E. Ogunsola, O. B. Ojuederie, and B. Emmanuel, "In vitro morphogenic responses of African yam bean (Sphenostylis stenocarpa (Hochst ex. A. Rich.) Harms) accessions to plant growth regulators," Plant Cell, Tissue and Organ Culture (PCTOC), vol. 127, no. 3, pp. 613-622, 2016.

[4] D. Potter and J. J. Doyle, "Origins of the African Yam bean (Sphenostylis stenocarpa, leguminosae): evidence from morphology, isozymes, chloroplast DNA, and linguistics," Economic Botany, vol. 46, no. 3, pp. 276-292, 1992.

[5] USDA, National Genetic Resources Program: Germplasm Resources Information Network-(GRIN), National Germplasm Resources Laboratory Beltsville, Maryland, MA, USA, 2009.

[6] O. B. Ojuederie, M. O. Balogun, S. R. Akande, S. Korie, and T. Omodele, "Intraspecific variability in agro-morphological traits of African yam bean Sphenostylis stenocarpa (Hochst ex. A. Rich) harms," Journal of Crop Science and Biotechnology, vol. 18, no. 2, pp. 53-62, 2015.

[7] J. Olasoji, S. R. Akande, and O. F. Owolade, "Genetic variability in seed quality of African yam beans (Sphenostylis stenocarpa Hochst. Ex A. Rich Harms)," African Journal of Agricultural Research, vol. 6, no. 27, pp. 5848-5853, 2011.

[8] A. N. Osuagwu and G. E. Nwofia, "Effect of spent engine oil on the germination ability of eleven accessions of African yam bean seeds (Sphenostylis sternocarpa Hochst ex A. Rich)
Harms," IOSR Journal of Agriculture and Veterinary Science, vol. 7, no. 1, pp. 59-62, 2014.

[9] B. D. Adewale, D. J. Dumet, I. Vroh-Bi et al., "Morphological diversity analysis of African yam bean (Sphenostylis stenocarpa Hochst. ex A. Rich.) Harms and prospects for utilization in germplasm conservation and breeding," Genetic Resources and Crop Evolution, vol. 59, no. 5, pp. 927-936, 2012.

[10] D. Oganale, "Nodulation and nitrogen fixation of African yam beam (Sphenostylis stenocarpa)," in Proceedings of the African Crop Science Society Conference, Cape Town, CA, USA, 2009.

[11] B. D. Adewale, A. Daniel, and A. C. Onye, "The nutritional potentials and possibilities in African yam bean for Africans," International Journal of AgriScience, vol. 3, no. 1, pp. 8-19, 2013.

[12] U. S. Ndidi, C. U. Ndidi, A. Olagunju et al., "Proximate, antinutrients and mineral composition of raw and processed (Boiled and Roasted) Sphenostylis stenocarpa seeds from Southern Kaduna, Northwest Nigeria," ISRN Nutrition, vol. 9, 2014.

[13] NRC National Research Council, Lost Crops of Africa: Volume II: Vegetables, The National Academies Press, Washington, DC, USA, 2009.

[14] O. B. Ojuederie and M. O. Balogun, "African yam bean (Sphenostylis stenocarpa) tubers for nutritional security," Journal of Underutilized Legumes, vol. 1, no. 1, pp. 56-68, 2019.

[15] T. Hussein, M. Urge, and G. Animut, "Effect of replacing soybean meal (Glycine max) with kidney bean (Phaseolus vulgaris) on egg quality parameter of white Leghorn layers," International Journal of Livestock Production, vol. 7, no. 6, pp. 33-40, 2016.

[16] M. O. Oke, S. S. Sobowale, and G. O. Ogunlakin, "Evaluation of the effect of processing methods on the nutritional and anti-nutritional compositions of two under-utilized Nigerian grain legumes," Pakistan Journal of Biological Sciences, vol. 16, no. 24, pp. 2015-2020, 2013.

[17] S. Ajibade, M. Balogun, O. Afolabi, K. Ajomale, and S. Fasoyiro, "Genetic variation in nutritive and anti-nutritive contents of African yam bean (Sphenostylis stenocarpa)," Tropical Science, vol. 45, no. 4, pp. 144-148, 2005.

[18] S. B. Fasoyiro, S. R. Ajibade, A. J. Omole, O. N. Adeniyan, and E. O. Farinde, "Proximate, minerals and antinutritional factors of some underutilized grain legumes in south-western Nigeria," Nutrition \& Food Science, vol. 36, no. 1, pp. 18-23, 2006.

[19] O. B. Ojuederie, M. O. Balogun, and M. T. Abberton, "Mechanism for pollination in African yam bean," African Crop Science Journal, vol. 24, no. 4, pp. 405-416, 2016.

[20] F. U. Eneh, R. N. Orjionwe, and C. S. Adindu, "Effect of african yam bean (Sphenostylis stenocarpa) on serum calcium, inorganic phosphate, uric acid, and alkaline phosphatase concentration of male albino rats," Journal of Agricultural Sciences, vol. 8, 2016.

[21] J. O. Popoola, A. E. Adegbite, O. O. Obembe et al., "Morphological intraspecific variabilities in African yam bean (AYB)(Sphenostylis stenocarpa Ex. A. Rich) Harms," Scientific Research and Essay, vol. 6, no. 3, pp. 507-515, 2011.

[22] O. Franca and D. Isioma, "Rat serum electrolytes and lipid profiles following administration of aqueous extract of Sphenostylis stenocarpa," Journal of Advances in Medical and Pharmaceutical Sciences, vol. 14, no. 4, pp. 1-8, 2017.

[23] J. K. Akintunde, J. A. Ajiboye, E. O. Siemuri et al., "Effects of anti-erectile dysfunction drug on some key tissues in healthy 
male rats," American Journal of Drug Discovery and Development, vol. 3, no. 2, pp. 32-46, 2013.

[24] G. O. Ogunlakin, M. O. Oke, G. O. Babarinde, and D. G. Olatunbosu, "Effect of drying methods on proximate composition and physico-chemical properties of cocoyam flour," American Journal of Food Technology, vol. 7, no. 4, pp. 245-250, 2012.

[25] E. O. Odebunmi, O. O. Oluwaniyi, A. M. Sanda, and B. O. Kolade, "Nutritional compositions of selected tubers and root crops used in Nigerian food preparations," International Journal of Chemistry, vol. 17, no. 1, pp. 37-43, 2007.

[26] AOAC, Official Methods of Analysis, Association of Official Analytical Chemists, AOAC, Arlington, VA, USA, 1984.

[27] C. O. Edeogu, F. C. Ezeonu, A. N. Okaka et al., "Proximate composition of staple food crops in ebonyi state (south eastern Nigeria)," International Journal of Biotechnology and Biochemistry, vol. 3, no. 1, pp. 1-8, 2007.

[28] O. B. Ojuederie, "Assessment of Genetic Diversity in African yam bean Sphenostylis stenocarpa (Hochst ex. A. Rich) Harms," Ph.D. thesis, University of Ibadan, London, UK, 2016.

[29] J. A. Ajiboye, O. L. Erukainure, E. E. Okoro, and G. Asieba, "Artesunate-induced testicular injury: oil from selected spices blend modulates redox homeostasis and exacerbates steroidogenesis in rat models," Clinical Nutrition Experimental, vol. 10, pp. 12-20, 2016.

[30] NRC National Research Council, Guide for the Care and Use of Laboratory Animals, National Academies Press, London, UK, 2011.

[31] T. Radovanovic, S. Borkovic-Mitic, B. Perendija et al., "Superoxide dismutase and catalase activities in the liver and muscle of barbel (Barbus barbus) and its intestinal parasite (Pomphoryinchus laevis) from the Danube river, Serbia," Archives of Biological Sciences, vol. 62, no. 1, pp. 97-105, 2010.

[32] K. O. Soetan, I. A. Adedara, and E. O. Farombi, "Lablab purpureus seeds disrupt hepatic and renal antioxidant status in male rats," Folia Veterinaria, vol. 60, no. 2, pp. 11-19, 2016.

[33] E. O. Farombi, M. C. Ugwuezunmba, T. T. Ezenwadu, M. O. Oyeyemi, and M. Ekor, "Tetracycline-induced reproductive toxicity in male rats: effects of vitamin $\mathrm{C}$ and $\mathrm{N}$-acetylcysteine," Experimental and Toxicologic Pathology, vol. 60, no. 1, pp. 77-85, 2008.

[34] S. Gowda, P. B. Desa, V. Hull et al., “A review on laboratory liver function tests," The Pan African Medical Journal, vol. 3, 2009.

[35] SAS Statistical Analysis System, SAS/STAT User's Guide: Vversion 9.3, SAS Institute, Cary, NC, USA, 2010.

[36] K. J. Chandra, A. S. Salman, A. Mohd et al., "Protection against FCA induced oxidative stress induced DNA damage as a model of arthritis and In-vitro anti-arthritic potential of Costus speciosus rhizome extract," International Journal of Pharmacognosy and Phytochemical Research, vol. 7, no. 2, pp. 383-389, 2015.

[37] R. S. Verma, A. Mehta, and N. Srivastava, "Comparative studies on chlorpyrifos and methyl parathion induced oxidative stress in different parts of rat brain: attenuation by antioxidant vitamins," Pesticide Biochemistry and Physiology, vol. 95, no. 3, pp. 152-158, 2009.

[38] M. G. Akande and U. S. Ahmed, "Taurine abated subacute dichlorvos toxicity," Toxicology Reports, vol. 4, pp. 463-466, 2017.

[39] S. Bhattacharya, "Reactive oxygen species and cellular defense system," in Free Radicals in Human Health and Disease,
V. Rani and U. C. S. Yadav, Eds., pp. 17-29, Springer, Berlin, Germany, 2015.

[40] G. Mao, G. A. Kraus, I. Kim, M. E. Spurlock, T. B. Bailey, and D. C. Beitz, "Effect of a mitochondria-targeted vitamin E derivative on mitochondrial alteration and systemic oxidative stress in mice," British Journal of Nutrition, vol. 106, no. 1, pp. 87-95, 2011.

[41] B. Wang, P. P. Van Veldhoven, C. Brees et al., "Mitochondria are targets for peroxisome-derived oxidative stress in cultured mammalian cells," Free Radical Biology and Medicine, vol. 65, pp. 882-894, 2013.

[42] G. Ozkurt-Bor, M. S. Aktas, I. Camkerten et al., "Erythrocyte superoxide dismutase, catalase activity and malondialdehit level in hypodermosis," Journal of Animal and Veterinary Advances, vol. 10, no. 1, pp. 84-86, 2011.

[43] K. O. Soetan and O. E. Oyewole, "The need for adequate processing to reduce the anti-nutritional factors in plants used as human foods and animal feeds: a review," African Journal of Food Sciences, vol. 3, no. 9, pp. 223-232, 2009.

[44] L. A. Nwaogu and A. C. Udebuani, "Effect of processing on the nutritional and toxicological components of Cleome rutidosperma seed," African Journal of Biotechnology, vol. 9, no. 2, 2010.

[45] V. F. Abioye, B. F. Olanipekun, and O. T. Omotosho, "Effect of varieties on the proximate, nutritional and anti-nutritional composition of nine variants of african yam bean seeds (Sphenostylis stenocarpa)," Donnish Journal of Food Science Technol, vol. 1, no. 2, pp. 17-21, 2015.

[46] E. N. Onyeike, E. O. Ayalogu, and S. G. Uzogara, "Influence of heat processing of African yam bean seed (Sphenostylis stenocarpa) flour on the growth and organ weights of rats," Plant Foods for Human Nutrition, vol. 48, no. 2, pp. 85-93, 1995.

[47] C. O. Alake and B. J. Porbeni, "Genetic variation and intraspecific diversity for agro-morphological and nutritional traits in African yam bean," Journal of Crop Improvement, vol. 34, no. 2, pp. 139-163, 2020.

[48] B. Ikhajiagbe and J. K. Mensah, "Genetic assessment of three colour variants of african yam bean (Sphenostylis stenocarpa) commonly grown in the midwestern region of Nigeria," International Journal of Modern Botany, vol. 2, no. 2, 2012. 